\title{
29 October 2007, Çameli earthquake and structural damages at unreinforced masonry buildings
}

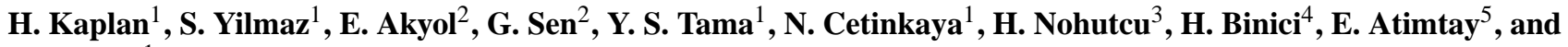 \\ A. Sarisin ${ }^{1}$ \\ ${ }^{1}$ Department of Civil Engineering, Pamukkale University, Kinikli, Denizli, Turkey \\ ${ }^{2}$ Department of Geological Engineering, Pamukkale University, Kinikli, Denizli, Turkey \\ ${ }^{3}$ Department of Civil Engineering, Celal Bayar University, Manisa, Turkey \\ ${ }^{4}$ Department of Civil Engineering, Kahramanmaras Sutcu Imam University, Kahramanmaras, Turkey \\ ${ }^{5}$ Department of Civil Engineering, Middle East Technical University, Ankara, Turkey
}

Received: 13 February 2008 - Revised: 17 April 2008 - Accepted: 8 July 2008 - Published: 26 August 2008

\begin{abstract}
A recent earthquake of $\mathrm{M}=4.9$ occurred on 29 October 2007 in Çameli, Denizli, which is located in a seismically active region at southwest Anatolia, Turkey. It has caused extensive damages at unreinforced masonry buildings like many other cases observed in Turkey during other previous earthquakes. Most of the damaged structures were non-engineered, seismically deficient, unreinforced masonry buildings. This paper presents a site survey of these damaged buildings. In addition to typical masonry damages, some infrequent, event-specific damages were also observed. Reasons for the relatively wide spread damages considering the magnitude of the event are discussed in the paper.
\end{abstract}

\section{Introduction}

Masonry structures located on seismically active regions of Turkey are mainly non-engineered seismically deficient buildings. Many people live in those unreinforced masonry structures, which constitute an important percentage of the building stock in Turkey. Unfortunately, they showed poor performance during previous earthquakes and most of the damages and casualties were resulted from these structures. However, in view of earthquake engineering, significant lessons were learned from the surveys of damaged masonry buildings after earthquakes (Bayraktar et al., 2007; Ramazi and Jigheh, 2006).

An earthquake of magnitude 4.9 occurred at 09:23 GMT on 29 October 2007 (ERC, 2007) in Çameli/Denizli, which

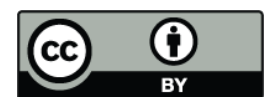

Correspondence to: G. Sen (gsen@pau.edu.tr) is located in a high seismicity region at southwest Anatolia of Turkey. 374 buildings were heavily and very heavily damaged and 333 buildings had from light to moderate damage (DOMPW, 2007) out of a total number of 2559 buildings in the disaster area, which means almost $28 \%$ of the buildings were damaged. Fortunately, the earthquake happened at daytime and no deaths were reported.

The most interesting point about this earthquake is the extensive damage to unreinforced masonry buildings. Since the magnitude of the event is quite low, no damages or very limited cracks were expected before the detailed investigations. However, the number of damaged buildings was far beyond the expectations. Characteristics of the earthquake are explained; and damage patterns and reasons for the extensive damages on masonry buildings are presented in this paper. Many of the damaged buildings were unreinforced stone masonry ones having low construction quality. Among the infrequent damage patterns of previous earthquakes, the slope/hill effect was an important cause of the damages. Another unusual cause of the damages was the use of regional masonry blocks, made from brittle marl deposits.

\section{Seismological and geotechnical issues}

\subsection{Seismological issues}

Horst and grabens on one of which Çameli Basin is formed are identical neotectonic shapes in west Anatolia. The basin that is directed in NE-SW direction is about $60 \mathrm{~km}$ in length and $40 \mathrm{~km}$ in width. It consists of fluvial-lacustrinal deposits and alluvial fans and it has roughly $500 \mathrm{~m}$ thickness (Fig. 1). The basement of the graben consists of metamorphic and ophiolitic rocks of the Lycian Nappes (Alçiçek et al., 2005).

Published by Copernicus Publications on behalf of the European Geosciences Union. 


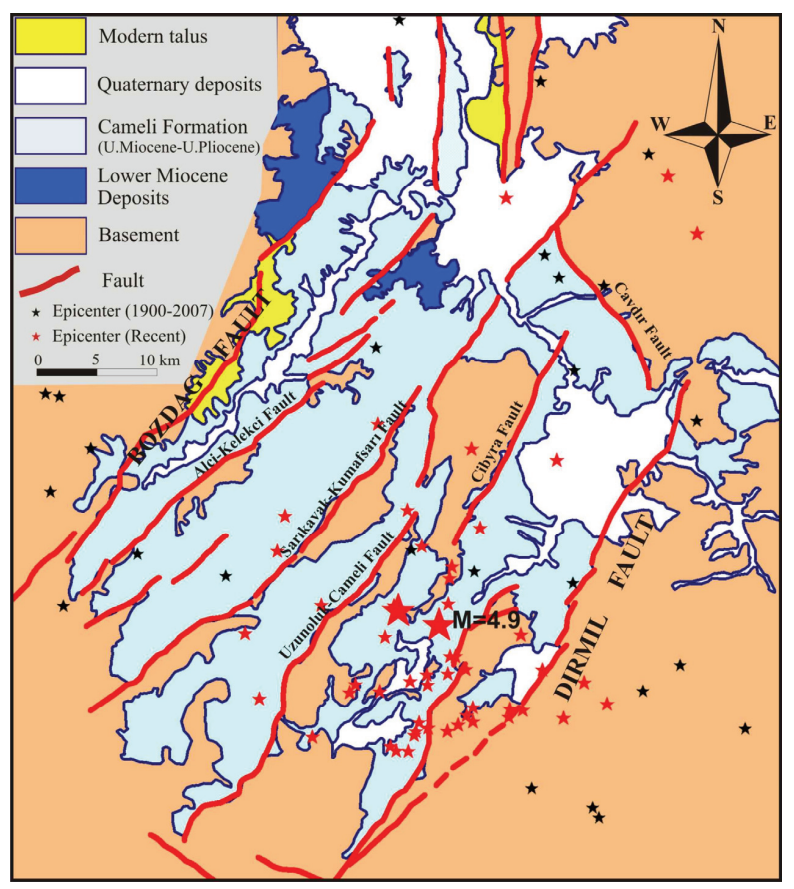

Fig. 1. Geological map of the investigation area, modified from (Alçiçek et al., 2006), and the recent and past earthquake epicenters.

The region shows high seismic activity that is caused by Gölhisar-Çameli Fault Zone. The zone includes a number of single faults in NE-SW direction, namely Bozdag, AlciKelekci, Sarikavak-Kumafsari, Uzunoluk-Çameli and Dirmil Faults. Figure 1 illustrates the earthquake epicenters, which occurred between 1900 and 2007. It clearly demonstrates the tectonic activity of the region.

\subsection{Geotechnical issues}

The soils beneath the building foundations range from silt to sand size in the survey area. However, these soils have "stiff" and "very stiff" consistency (Fig. 2), which means they should have small soil amplification factor. Some parts of the soils have rock-hard view like marl.

The settlement is forced to move to the hilly area due to the rugged morphology of Çameli. Many of the damaged buildings have been located on the hills rather than plains. Therefore, the topographic amplification may increase the level of the damages, like some previously reported cases (Capua et al., 2006; Jibson, 1987; Finn, 1991). Some researchers reported that ground accelerations increase up to $2.5 \times$ on the hills (Jibson, 1987) (Fig. 3). For some cases in the survey area, the slope height where the buildings are constructed reaches up to $140 \mathrm{~m}$. The ratio of the peak ground acceleration to peak crest acceleration is 0.36 at the bottom of hills and it rises to 0.5 on the hills. These values suggest that peak crest accelerations on the hills are about $50 \%$ more than the values on plains.
Table 1. Peak acceleration values of the event from nearest 5 stations (ERC, 2007).

\begin{tabular}{lllll}
\hline \multirow{2}{*}{$\begin{array}{l}\text { Recording } \\
\text { station }\end{array}$} & $\begin{array}{l}\text { Epicentral } \\
\text { distance } \\
\end{array}$ & \multicolumn{3}{c}{ Peak Ground Acceleration $\left(\mathrm{cm} / \mathrm{s}^{2}\right)$} \\
& $\mathrm{km})$ & component & $\begin{array}{l}\text { E-W } \\
\text { component }\end{array}$ & $\begin{array}{l}\text { Upper } \\
\text { component }\end{array}$ \\
\hline Çameli & 2.67 & 56.58 & 42.81 & 28.09 \\
Köyceğiz & 57.01 & 21.12 & 10.16 & 5.37 \\
Muğla & 86.59 & 1.42 & 1.16 & 1.24 \\
Fethiye & 52.12 & 13.24 & 12.07 & 5.96 \\
Denizli & 84.62 & 1.45 & 1.64 & 0.99 \\
\hline
\end{tabular}

Table 2. Official damage statistics (DOMPW, 2007).

\begin{tabular}{llll}
\hline Village & $\begin{array}{l}\text { Total } \\
\text { number of } \\
\text { buildings }\end{array}$ & $\begin{array}{l}\text { Heavy/ } \\
\text { very heavy } \\
\text { damage }\end{array}$ & $\begin{array}{l}\text { Light/ } \\
\text { moderate } \\
\text { damage }\end{array}$ \\
\hline Arikaya & 300 & 5 & 5 \\
Cevizli & 250 & 67 & 54 \\
Elmali & 450 & 118 & 127 \\
Emecik & 160 & 7 & 8 \\
Gursu & 150 & 9 & 9 \\
Karabayir & 240 & 0 & 2 \\
Kirazliyayla & 360 & 18 & 27 \\
Kolak & 260 & 1 & 3 \\
Sarikavak & 120 & 0 & 8 \\
Sofular & 100 & 50 & 35 \\
Tascilar & 169 & 99 & 55 \\
Total & 2559 & 374 & 333 \\
\hline
\end{tabular}

\subsection{Characteristics of the earthquake}

Peak values of the acceleration histories, which were recorded by 5 stations within a $100 \mathrm{~km}$ range from the epicenter for Çameli earthquake, are given in Table 1. The nearest station to epicenter was Çameli station, having an epicentral distance of $2.67 \mathrm{~km}$. This record is filtered by Butterworth band-pass filter, and then applied to the frequencies below $0.1 \mathrm{~Hz}$ and those above $25 \mathrm{~Hz}$. Baseline correction was also carried out. All filtering and correction works were performed with Seismosignal (SS, 2007). The corrected components of the record are shown in Fig. 4.

Spectral accelerations of the records were calculated for damping values of 0\%, 2\%, 5\% and 10\% (Fig. 5). Damping ratios between $2 \%$ to $10 \%$ are proposed by different studies (Sucuoglu and Erberik, 1997; Freeman, 2004; Tomazevic et al., 2006) indicating that damping in masonry walls is achieved by friction forces and may increase significantly after crack formation (Gulkan and Langenbach, 2004). However, these studies are mostly related with reinforced masonry. In the existing literature, nonlinear damping characteristic of the unreinforced masonry is not well established. 


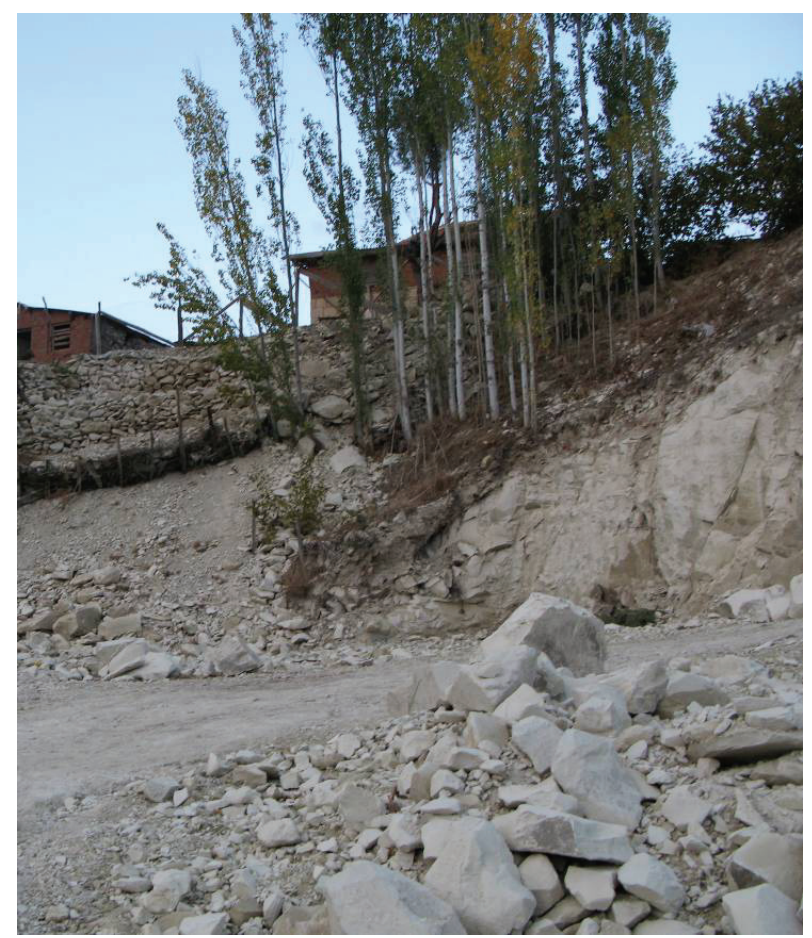

Fig. 2. A typical view of the rugged morphology and soils of the area.

On the other hand, structural and material details of the damaged buildings due to Çameli earthquake yielded to a very brittle mode of failure as the walls were unreinforced. Construction technique of these buildings causes lower friction forces in the cracks with respect to reinforced masonry, which limits the increase in effective nonlinear damping. Therefore, it can be said that nonlinear effective damping of the damaged unreinforced masonry structures was even less than $10 \%$ of the critical damping.

\section{Damages at masonry buildings}

Masonry buildings were usually constructed by using locally available stone and marl blocks in rural settlement areas of Çameli. Most of the buildings were one-storey and had a light roof with a wooden skeleton. Under the skeleton a light ceiling was usually formed. This type of light roofing significantly reduces the seismic demands; however, it cannot provide any diaphragm effect. These non-engineered unreinforced masonry buildings were not earthquake resistant and were not complied with Turkish seismic codes (MPW, 1975; MPW, 1998; MPW, 2007).

Masonry construction technique was very similar in all villages in the disaster area. Walls were formed by two wythes (inner and outer). Outer wythes were usually constructed painstakingly to get a good-looking view. It was observed that these wythes were not connected to each other properly. Moreover, in traditional construction style, side walls were

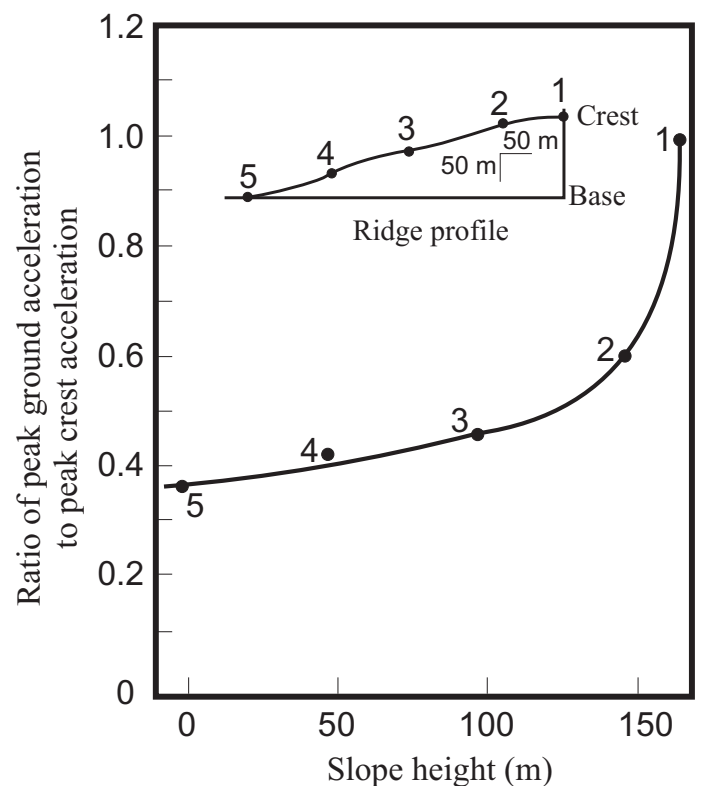

Fig. 3. Effect of slope height on peak ground acceleration (Jibson, 1987).
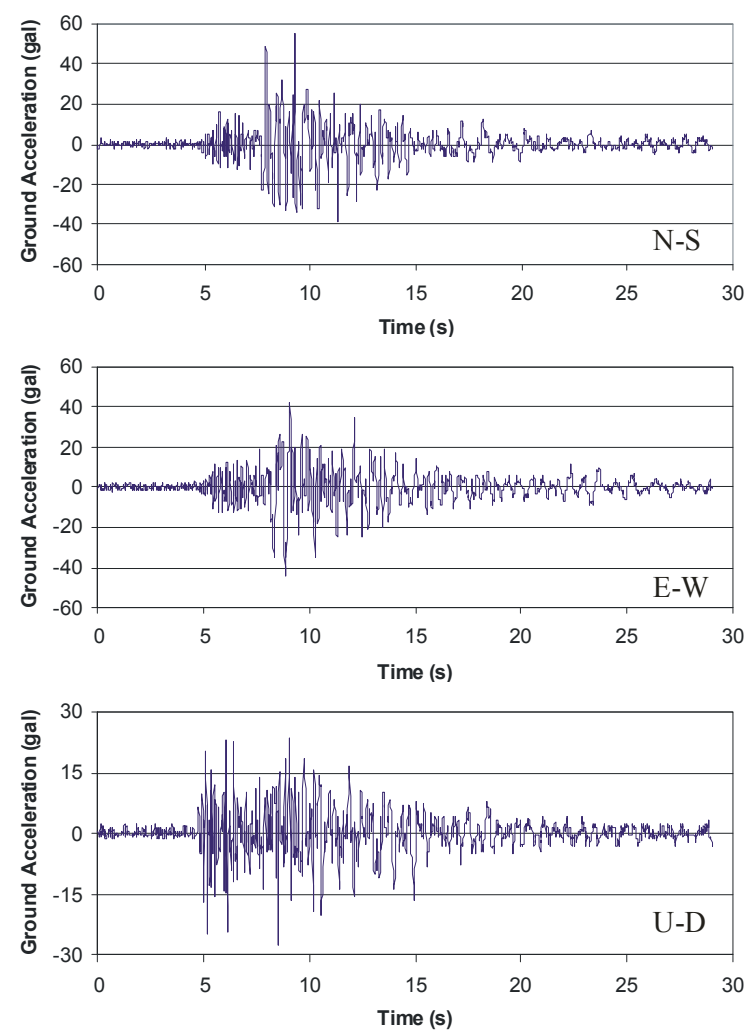

Fig. 4. Corrected and filtered N-S, E-W and U-D components of acceleration record of Çameli station.

constructed before the partition walls without achieving any connection in between them. Therefore, detailing of wall sections and wall connections were seismically deficient. 

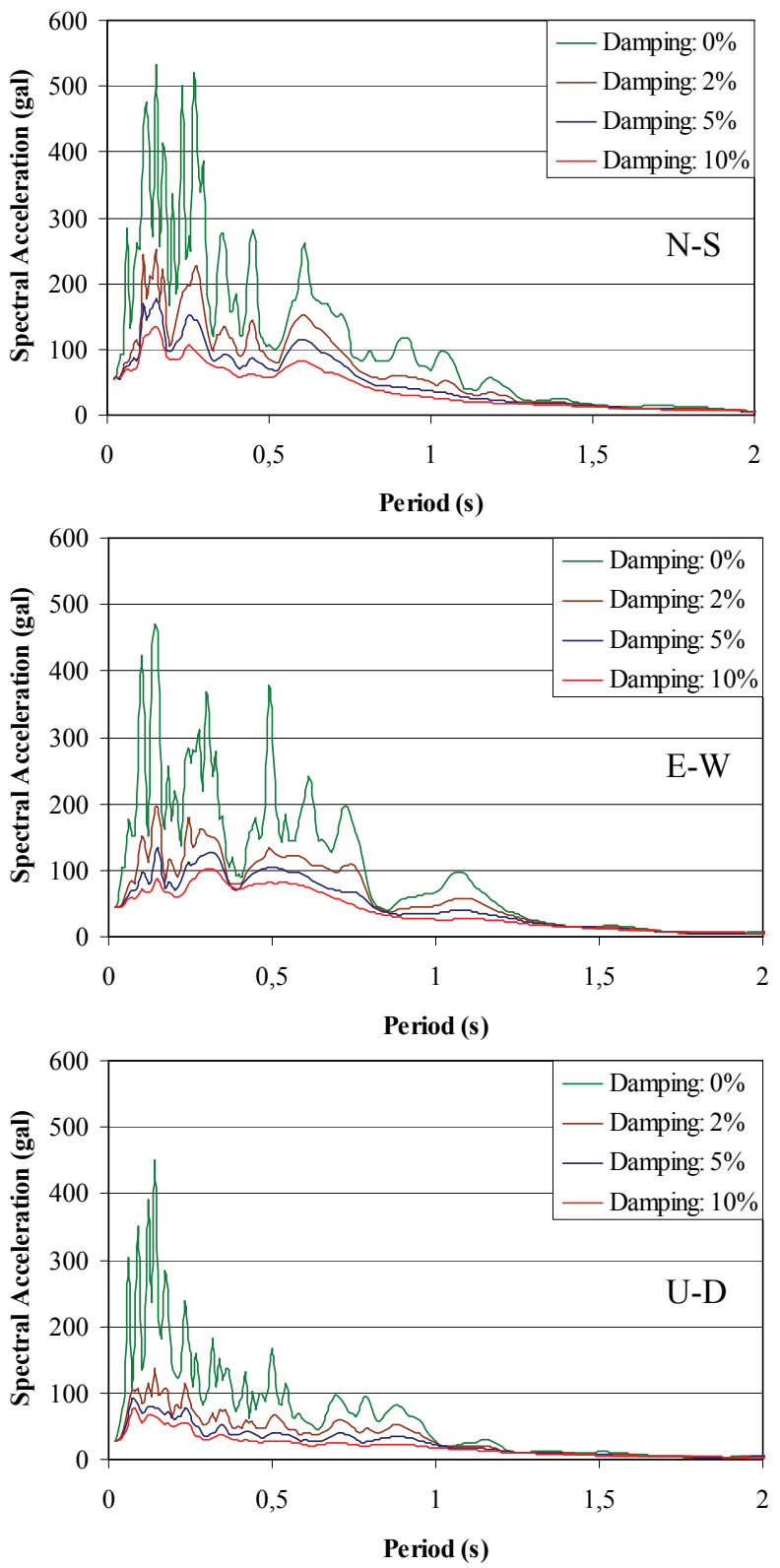

Fig. 5. Acceleration spectrums of the record for $0 \%, 2 \%, 5 \%, 10 \%$ damping ratios.

Although, the magnitude and spectral acceleration values of the Çameli Earthquake was quite low, many masonry buildings were heavily damaged and a considerable amount of buildings in the region had some level of damage due to above mentioned construction practice. Local Office of Ministry of Public Works and Settlement reported that 374 buildings in the region were damaged heavily or very heavily by the quake. Total number of damaged buildings was 707 (DOMPW, 2007). More detailed official damage statistics are given in Table 2.

Reasons for the damages are worth investigating because

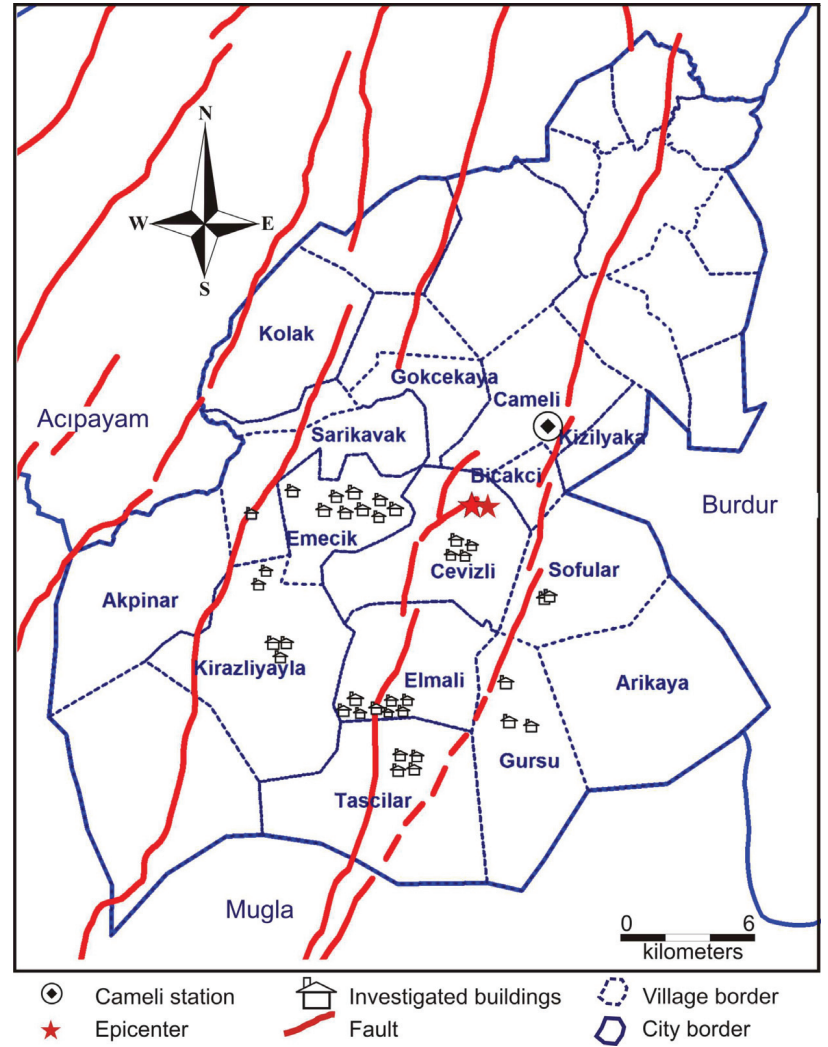

Fig. 6. Locations of epicenter and the investigated buildings in the affected area.

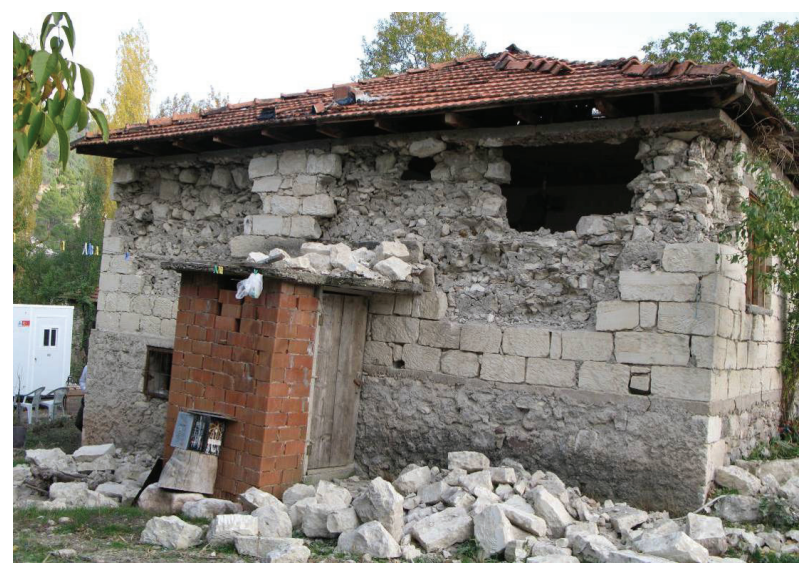

Fig. 7. Typical damage pattern in Çameli earthquake.

of the extensive damage despite the low magnitude of the earthquake. For this purpose, all of the disaster area was surveyed and detailed studies were carried out on the damaged buildings. Locations of the investigated buildings and the epicenter of the earthquake are shown in Fig. 6. 


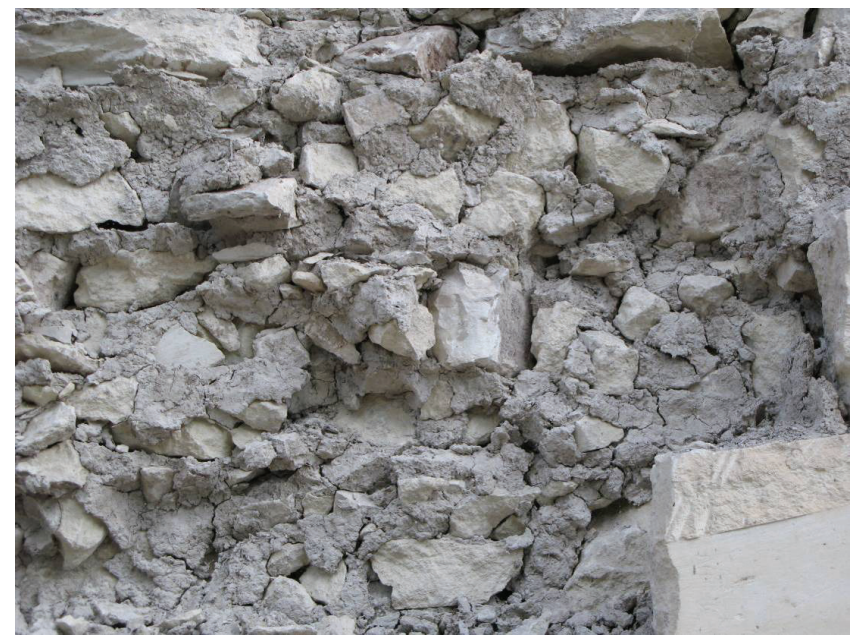

Fig. 8. Bad profile of a damaged wall.

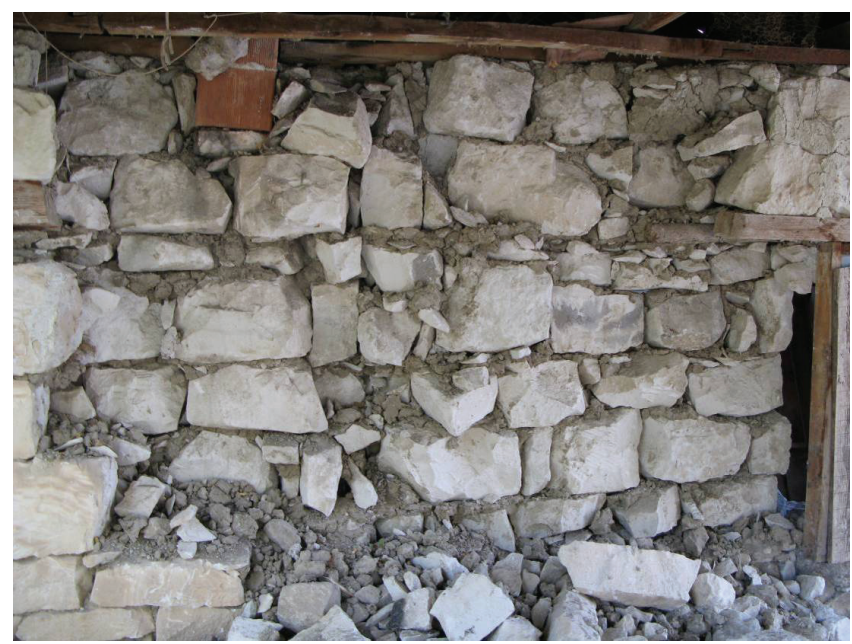

Fig. 9. Unconnected outer and inner wythes.

During the investigations, the main reasons for the poor performance of unreinforced masonry buildings were determined. These may be listed as the use of improper masonry units with inappropriate wall cross sections, the inadequate or no connection of crossing walls, the irregular wall openings, out-of-plane failures and amplification due to topographical irregularities. All of these deficiencies are discussed below in detail with the examples of damaged buildings.

\subsection{Use of improper wall material and wall cross section}

One of the most common mistakes in the construction of the unreinforced masonry buildings in the region was the use of improper masonry units. Stone and marl blocks were the wall materials commonly used in the damaged buildings.

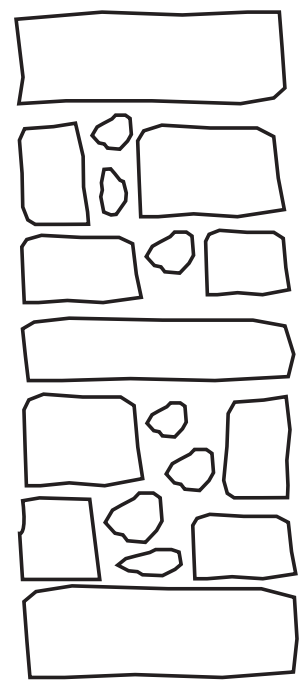

Earthquake resistant

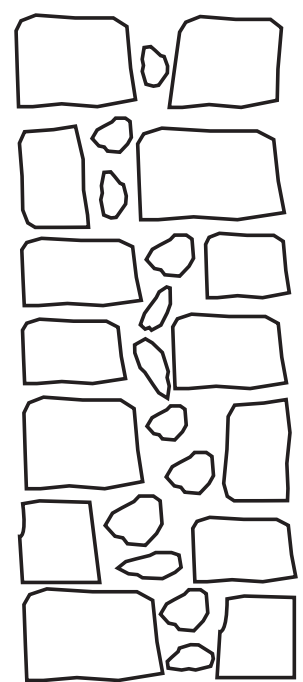

Earthquake prone
Fig. 10. Typical cross sections of earthquake resistant and fragile stone masonry walls.

Marl blocks have low strength and ductility values. When the natural stone blocks are used as a wall material, selected stones usually do not have a proper shape to be used in the masonry walls; instead they have smooth and oval surfaces. Walls were formed by varying sizes of stone blocks, from 4$5 \mathrm{~cm}$ to $30 \mathrm{~cm}$. These variations made it impossible to form an overlapping wall section. In addition to non-overlapping wall sections, walls were composed of an inner and an outer wythes, which were not connected to each other by interlocking elements. This bad wall configuration also made the walls more prone to out-of-plane failure, as the net length of the outer wythes of walls increased considerably. Some examples of these types of damages are shown in Figs. 7-9. Typical wall section observed at the site is compared with an earthquake resistant section in Fig. 10, where lack of connection between outer and inner wythes can be seen easily.

\subsection{Inadequate or no connection of crossing walls}

Although, masonry units have to be interlocked to satisfy a proper connection in crossing sections of walls, they were not connected or their connection was very poor in most of the damage cases. Typical cases of such damages are shown in Fig. 11. This is also proven by a building which was damaged during its construction (Fig. 12). External walls were constructed before the partition walls. Due to this bad connection detail of the crossing walls, safety of connections is relied on tensile strength of the mortar used for connection.

These type of deficiencies were not limited to external partition wall connections. At the corners of the buildings, where two external walls meet, masonry units were not overlapped properly to ensure an earthquake-resistant connection (Fig. 11). 

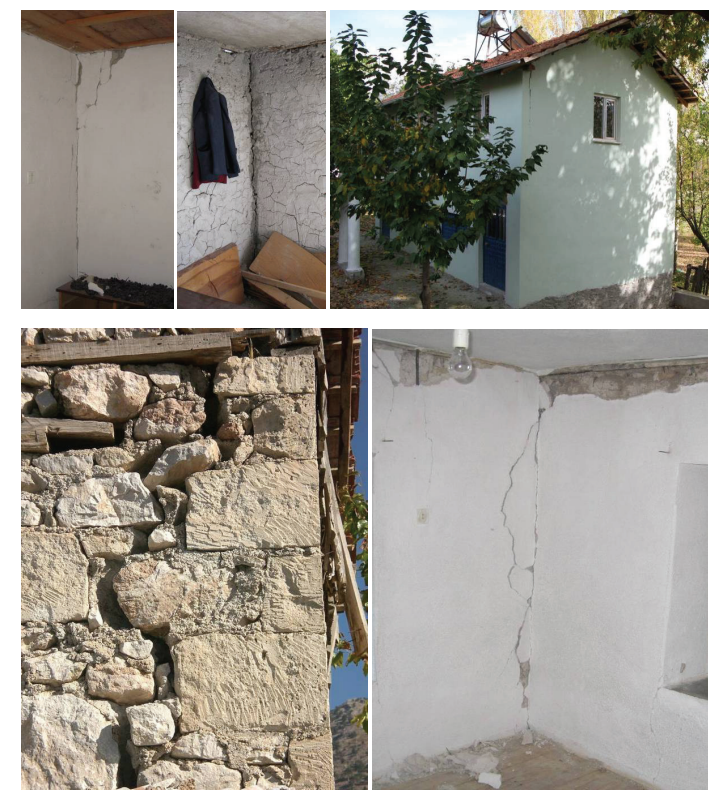

Fig. 11. Damages observed at connection of crossing walls.

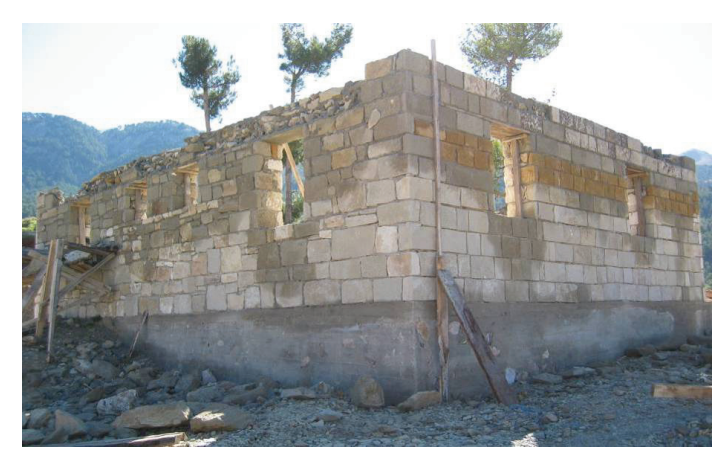

Fig. 12. Damaged building during its construction without partition walls.

\subsection{Damages due to wall openings}

As the masonry walls are the only load resisting mechanisms of the masonry buildings, wall openings should be regular and minimized as much as possible in order to improve earthquake resistance. Seismic design codes give the rules about these openings, restricting distance between the two openings, distance between an opening and a corner, etc. (MPW, 1975; MPW, 1998; MPW, 2007). For example, the new seismic code (MPW, 2007) limits the minimum distance between two openings as $1 \mathrm{~m}$ for seismic zone 1 and minimum allowable distance between an opening and a building corner is $1.5 \mathrm{~m}$.

Two examples of damages due to wall openings are given in Figs. 13 and 14. The problem in the former is the short distance between two adjacent windows. In the latter figure

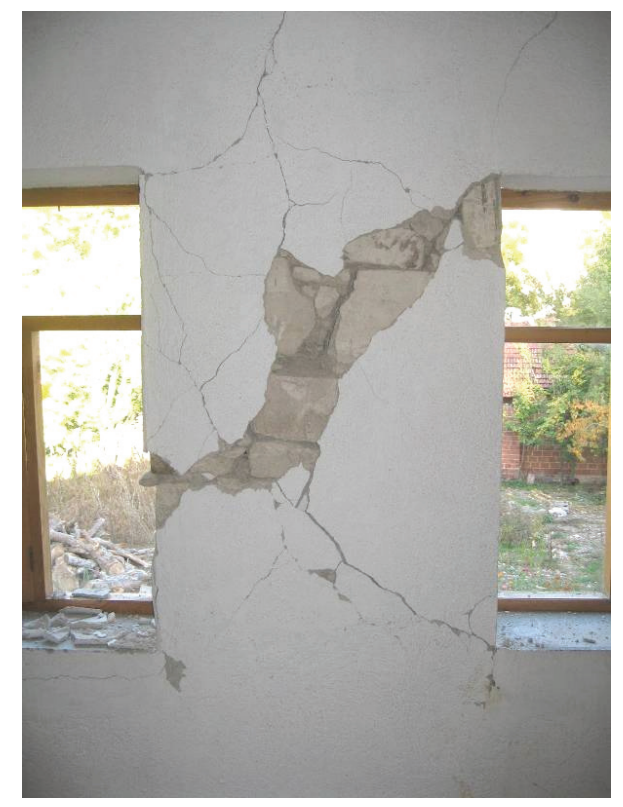

Fig. 13. Damage between two wall openings.

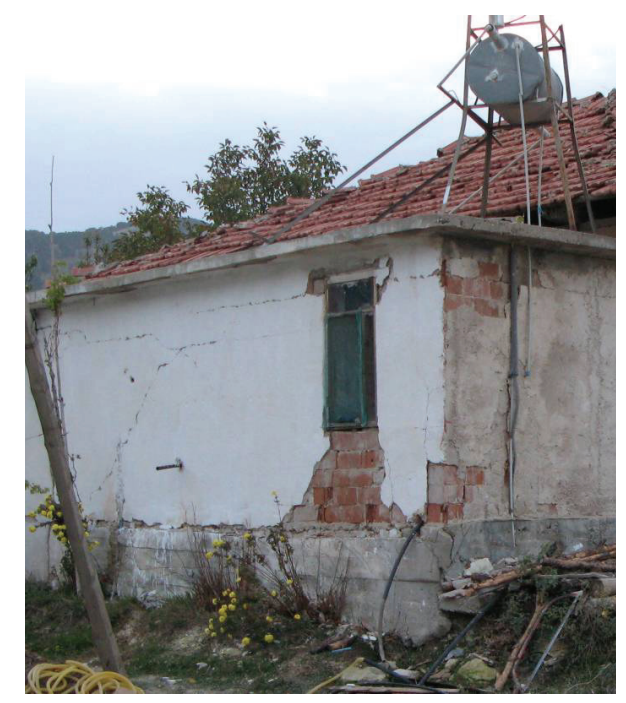

Fig. 14. Damage concentrated around wall opening near the building corner.

the problem is the short distance between the opening and the building corner. Due to this wall formation, damage was concentrated around the opening.

\subsection{Out-of-plane failures}

Out-of-plane failure is an important component of the complex nonlinear masonry behavior. This type of failures may result from the combination of several deficiencies. For example, long unsupported, slender walls, and improper wall section formation (like unconnected inner and outer wythes) 


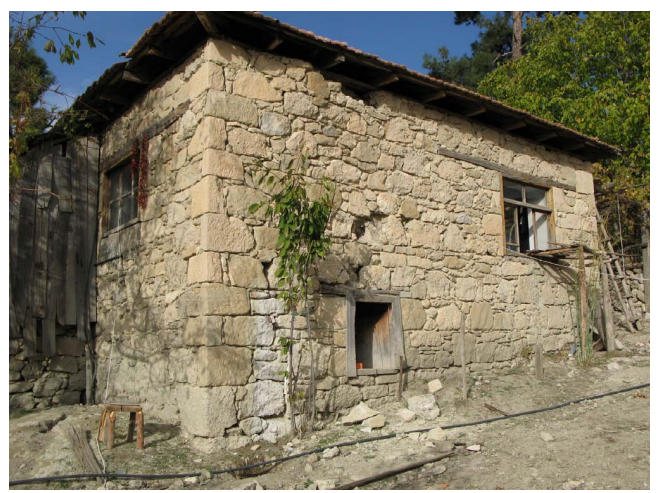

Fig. 15. Out of plane failure due to lack of bond beam.
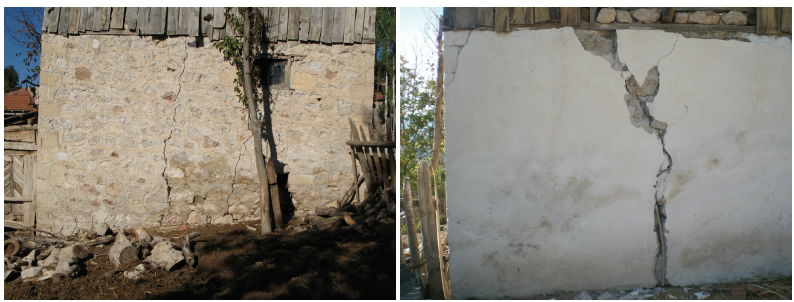

Fig. 16. Out of plane failure due to long unsupported wall length.

are some of those deficiencies. The lack of bonding beams at the top of the walls and having a light roof with insufficient in-plane rigidity, which does not provide diaphragm effect, are also important reasons of this type of damage (Fig. 15).

Another example of out-of-plane failure due to unsupported wall length is given in Fig. 16. Unsupported length of walls in plan is beyond the code limits, as the building is used as animal shed, which did not have any partitioning wall. Unsupported wall length is not only due to improper partition wall configuration but also unconnected wythes. A typical example of that type is given in Fig. 7. Net length of slender outer wythe was increased significantly and it failed finally.

\subsection{Damages due to topographical irregularities}

Topographical characteristics of the Çameli Basin played an important role for extensive damages in the region. Many of the damaged buildings were located on a hilly and rugged terrain. According to some corroborative studies, local topographical irregularities on ground surface may affect ground acceleration significantly (Kramer, 1996). Because of amplified ground accelerations, the number of damaged buildings increased significantly. Some damages on a building located on a hill are shown in Fig. 17. Due to the concentration of seismic energy and amplification of the ground acceleration at the top of the hill, damage level of the building is heavier than those located on the foot of the hill. It is also worth noting that cracks on the ground and on the top of the hillside are observed at the same place (Fig. 18).

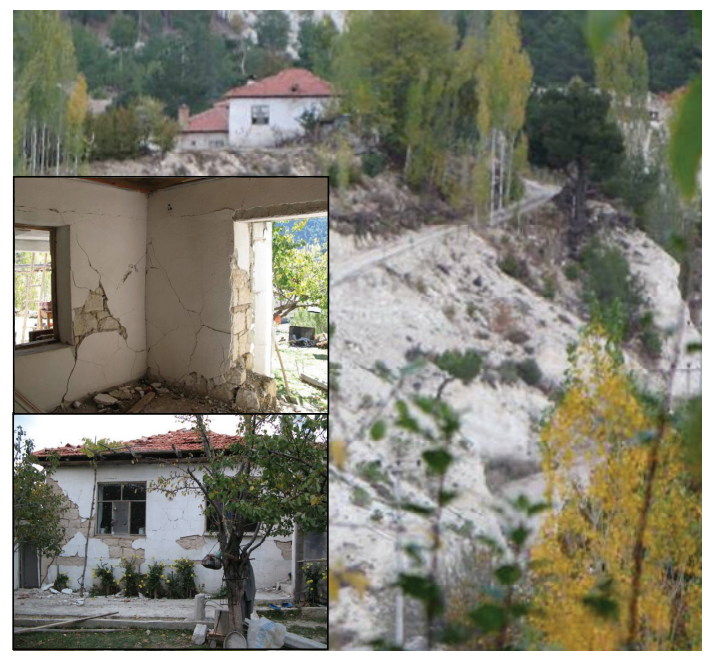

Fig. 17. Damaged building due to slope/hill affect.

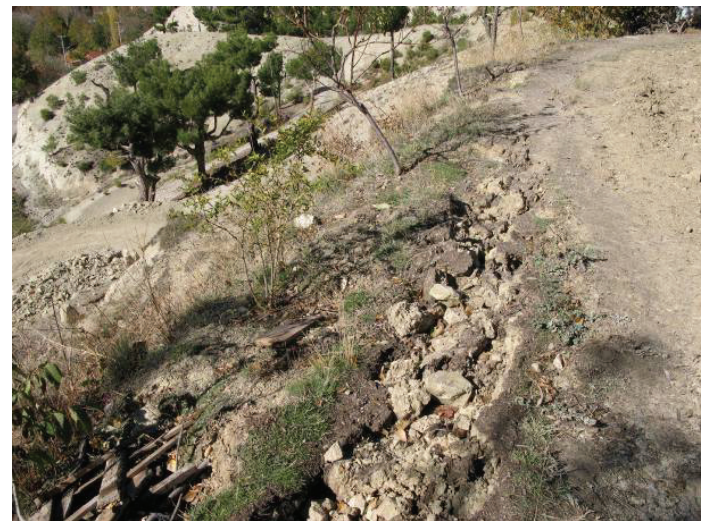

Fig. 18. Cracks on the ground at top of hillside.

\section{Results and discussion}

Çameli located on the highest seismic risk zone (Zone 1) of Turkey, is a south western Anatolian city. Although Çameli Earthquake is a relatively small event, it caused extensive damages on unreinforced masonry structures. Results of the survey on damaged structures are presented in the paper.

Damages concentrated on rural settlement areas, which were mostly comprised of one-storey unreinforced masonry structures. A considerable ratio of those structures was constructed by masonry blocks made of marl, which can abundantly be found in the region. Materials and construction techniques of these structures did not provide any earthquake resistance.

Most important defects of the damaged masonry structures were the lack of interlocking units between external and internal wythes of the wall sections and lack of connection between crossing walls. Both of them cause an increase in the possibility of out-of-plane behavior, as their formation increases net length of the walls or wythes. 
Another frequent structural defect was the lack of bond beams at the top of walls. Walls without bond beams were more susceptible to damage under seismic excitations. Mostly, light timber roof was placed directly on the walls. Such a structural configuration does not provide a diaphragm and increases fragility of the buildings. Due to free end at the top of walls, probability of out-of-plane failure mechanisms increases. On the other hand, this light roofing decreases seismic demands. In case of a heavy roof, which is mostly observed at Eastern Anatolia, damages would probably be heavier (Bayraktar et al., 2007).

Formation of irregular wall openings was another common problem. Usually, crack propagation was concentrated around the openings near the corners of the walls.

Besides structural considerations, local soil conditions played an important role for damages due to the earthquake. Peak ground acceleration recorded at the nearest station in Çameli city center ( $2.67 \mathrm{~km}$ away from epicenter) was less than 60 gals. Soil amplification due to slope hill effect and local soil conditions might increase ground accelerations. This was probably one of the reasons for the damages.

Masonry buildings in Turkey, generally have aforementioned deficiencies, due to which, many unreinforced masonry buildings were damaged during previous earthquakes. In the recent history, in addition to devastating 1999 Marmara $(M=7.4)$ and 1992 Erzincan $(M=6.7)$ Earthquakes, moderate events of 1984 Erzurum-Balkaya (M=5.7), 1995 Dinar ( $M=6.0), 1999$ Erzurum-Şenkaya $(M=5.1), 2000$ Çankir (M=5.9), 2002 Çay-Afyon ( $M=6.0) 2003$ Bingöl, $(\mathrm{M}=6.4)$ and 2003 Denizli-Buldan $(\mathrm{M}=5.5)$ caused damages at many non-engineered unreinforced masonry buildings. After Çameli Earthquake, which may not even be considered as a moderate earthquake, it is revealed once again that Turkish masonry buildings are highly susceptible against seismic forces especially in rural areas, where inadequate or no engineering services are available. It is essential to take necessary precautions to reduce seismic damages in masonry structures. On the other hand, it can be anticipated that rural settlement areas in Turkey will be devoid of engineering services for some decades. Therefore, education of foreman on seismic resistant masonry construction and increasing public awareness must be the preceding subjects for damage mitigation works in rural areas.

Acknowledgements. Authors thank for the support given by the Scientific and Technological Research Foundation of Turkey under the grant number of 106M116.

Edited by: M. Contadakis

Reviewed by: two anonymous referees

\section{References}

Alçiçek, M. C., Kazanci, N., and Özkul, M.: Multiple rifting pulses and sedimentation pattern in the Çameli Basin, southwestern Anatolia, Turkey, Sediment. Geol., 173, 409-431, 2005.

Alçiçek, M. C., Ten Veen, J. H., and Özkul, M.: Neotectonic development of the Çameli Basin, southwestern Anatolia, Turkey, Tectonic Development of the Eastern Mediterranean Region Geological Society, London, Special Publications, 260, 591-611, 2006.

Bayraktar, A., Coşkun, N., and Yalçin, A.: Damages of masonry buildings during the July 2, 2004 Doğubayazit (Ağri) earthquake in Turkey, Eng. Fail. Anal., 14, 147-157, 2007.

Capua, G. D., Curti, E., Lemme, A., Peppoloni, S., and Podestà, S.: Simplified parameters for the evaluation of site effects in the seismic risk analyses of monuments, First European Conference on Earthquake Engineering and Seismology, Geneva, Paper No. 656, 2006.

DOMPW: Çameli earthquake damage assessment report, Denizli Office of Ministry of Public Works and Settlement, 2007 (in Turkish).

ERC: Earthquake Research Center, www.deprem.gov.tr, last access: 3 November 2007.

Finn, W. D. L.: Assessment of the liquefaction aspects of the microzonation, Proceedings Fourth International Conference on Microzonation, Earthquake Research Institute, Stanford University, Palo Alto, California, 1, 199-259, 1991.

Freeman, S. A.: Review of the development of the capacity spectrum method, ISET J. Earthq. Technol., 41, 1-13, 2004.

Gulkan, P. and Langenbach, R.: The earthquake resistance of traditional timber and masonry dwellings in Turkey, 13th World Conference on Earthquake Engineering, Vancouver, Canada, Paper No. 2297, 2004

Jibson, R.: Summary on research on the effects of topographic amplification of earthquake shaking on slope stability, USGS, California, Open File Report, No. 87-268, 1987.

Kramer, S. L.: Geotechnical Earthquake Engineering, Prentice Hall, New Jersey, 1996.

MPW: Regulations for structures to be built in disaster areas, Ministry of Public Works and Settlement, Ankara, 1975 (in Turkish).

MPW: Regulations for structures to be built in disaster areas, Ministry of Public Works and Settlement, Ankara, 1998 (in Turkish).

MPW: Regulations for structures to be built in disaster areas, Ministry of Public Works and Settlement, Ankara, 2007 (in Turkish).

Ramazi, H. and Jigheh, H. S.: The Bam (Iran) earthquake of december 26, 2003: From an engineering and seismological point of view, J. Asian Earth Sci., 27, 576-584, 2006.

SS: SeismoSignal, Seismosoft, www.seismosoft.com, last access: 3 November 2007.

Sucuoglu, H. and Erberik, A.: Performance evaluation of a threestorey unreinforced masonry building during the 1992 Erzincan earthquake, Earthq. Eng. Struct. D., 26, 319-336, 1997.

Tomaževiè, M., Lutman, M., and Bosiljkov, V.: Robustness of hollow clay masonry units and seismic behaviour of masonry walls, Constr. Build. Mater., 20, 1028-1039, 2006. 